\title{
COMPARATIVE ANATOMY AND HISTOCHEMISTRY OF FRUITS OF FOUR VARIETIES OF Hancornia speciosa GOMES (APOCYNACEAE)
}

Anatomia comparativa e histoquímica de frutos de quatro variedades de Hancornia speciosa Gomes (Apocynaceae)

Anatomía e histoquímica comparativa de frutos de cuatro variedades de Hancornia Desafios speciosa Gomes (Apocynaceae)

Dayana Figueiredo Abdalla*1, Indiara Nunes Mesquita Ferreira ${ }^{2}$, Moemy Gomes de Moraes $^{3}$, Eli Regina Barboza de Souza ${ }^{4}$

${ }^{1}$ Doutoranda pelo Programa de Pós-Graduação em Agronomia, Universidade Federal de Goiás, Goiânia, Goiás, Brasil e professora do Instituto Federal de Educação, Ciência e Tecnologia de Goiás - Campus Itumbiara, Goiás, Brasil.

${ }^{2}$ Doutoranda pelo Programa de Pós-Graduação em Agronomia, Universidade Federal de Goiás, Goiânia, Goiás, Brasil.

${ }^{3}$ Laboratório de Fisiologia Vegetal, Departamento de Botânica, Instituto de Ciências Biológicas, Universidade Federal de Goiás, Goiânia, Goiás, Brasil.

${ }^{4}$ Escola de Agronomia, Universidade Federal de Goiás, Goiânia, Goiás, Brasil.

*Correspondência: Programa de Pós-Graduação em Agronomia, Universidade Federal de Goiás, Av. Esperança s/n, Campus Samambaia, Goiânia, Goiás, Brasil. CEP: 74690-900. E-mail dayanaabdallabio@ gmail.com.

\section{RESUMO}

Hancornia speciosa Gomes, conhecida como mangaba ou mangabeira, é uma espécie vegetal da família Apocynaceae com variedades botânicas ocorrendo em várias regiões do Brasil. Quatro variedades diferentes de H. speciosa ocorrem no bioma Cerrado. As características anatômicas contribuem para a identificação taxonômica de plantas, incluindo aquelas de órgãos isolados como folhas, raízes, caules, frutos e sementes. Assim, o objetivo do presente trabalho foi investigar características anatômicas e histoquímicas das principais classes de metabólitos dos frutos de H. speciosa var. pubescens, H. speciosa var. gardneri, H. speciosa var. speciosa e H. speciosa var. cuyabensis ocorrrentes no bioma Cerrado. Os frutos foram coletados, preservados e fixados seguindo métodos usuais para análises anatômicas e histoquímicas. Os frutos de todas as variedades analisadas de $H$. speciosa apresentaram exocarpo uniestratificado com presença de estômatos; mesocarpo bem desenvolvido com células parenquimáticas, idioblastos com acúmulos de compostos fenólicos, numerosos laticíferos e poucos feixes vasculares; o endocarpo é uniestratificado e circunda o tegumento da semente. Compostos fenólicos, látex, lipídios e proteínas foram encontrados em localizações semelhantes nos frutos das diferentes variedades. A única diferença observada entre as variedades foi a ocorrência de tricomas no exocarpo.

Palavras-chave: Mangaba. Metabólitos. Tricomas. 
Hancornia speciosa Gomes, known as mangaba or mangabeira, is a plant species of the Apocynaceae family with botanical varieties occurring in several regions of Brazil. Four different varieties of H. speciosa occur in the Cerrado biome. The anatomical characteristics contribute to the taxonomic identification of plants, including those of isolated organs such as leaves, roots, stems, fruits and seeds. Thus, the aim of the present work was to investigate anatomical and histochemical characteristics of the main classes of metabolites of $H$. speciosa var. pubescens, $H$. speciosa var. gardneri, $H$. speciosa var. speciosa and $H$. speciosa var. cuyabensis occurring in the Cerrado biome. The fruits were collected, preserved and fixed following the usual methods for anatomical and histochemical analysis. The fruits of all analyzed varieties of $H$. speciosa presented uni-stratified exocarp with the presence of stomata; well-developed mesocarp with parenchymal cells, idioblasts with accumulations of phenolic compounds, numerous laticifers and few vascular bundles; the endocarp is uni-stratified and surrounds the seed coat. Phenolic compounds, latex, lipids and proteins were found in similar locations in the fruits of the different varieties. The only difference observed between the varieties was the occurrence of trichomes in the exocarp.

Keywords: Mangaba. Metabolites. Trichomes.

\section{RESUMEN}

Hancornia speciosa Gomes, conocida como mangaba o mangabeira, es una especie vegetal de la familia Apocynaceae con variedades botánicas que se encuentran en varias regiones de Brasil. En el bioma del Cerrado se encuentran cuatro variedades diferentes de H. speciosa. Las características anatómicas contribuyen a la identificación taxonómica de las plantas, incluidas las de órganos aislados como hojas, raíces, tallos, frutos y semillas. Así, el objetivo del presente trabajo fue investigar las características anatómicas e histoquímicas de las principales clases de metabolitos de H. speciosa var. pubescens, $H$. speciosa var. gardneri, $H$. speciosa var. speciosa y $H$. speciosa var. cuyabensis ocurre en el bioma del Cerrado. Los frutos fueron recolectados, conservados y fijados siguiendo los métodos habituales de análisis anatómico e histoquímico. Los frutos de todas las variedades analizadas de H. speciosa presentaron exocarpio uniestratificado con presencia de estomas; mesocarpio bien desarrollado con células parenquimatosas, idioblastos con acumulación de compuestos fenólicos, numerosos productos lácteos y pocos haces vasculares; el endocarpio está uni-estratificado y rodea la cubierta de la semilla. Se encontraron compuestos fenólicos, látex, lípidos y proteínas en lugares similares en los frutos de las diferentes variedades. La única diferencia observada entre las variedades fue la aparición de tricomas en el exocarpio.

Descriptores: Mangaba. Metabolites. Tricomas.

\section{INTRODUCTION}

Hancornia speciosa Gomes, known as mangaba or mangabeira, is a fruit native to Brazil belonging to the family Apocynaceae Juss. The species is distributed in the Midwest, North, Northeast and Southeast regions of the country (LEDERMAN et al., 2000). It is the only species of the genus Hancornia Gomes, however, it was initially divided into six varieties (MONACHINO, 1945): H. speciosa Gomes var. speciosa, $H$. speciosa var. cuyabensis Malme, $H$. speciosa var. gardneri (A. DC.) Mierse, H. speciosa var. pubescens (Nees \& Mart.) Müll. Arg., H. speciosa var. maximiliani A. DC. and H. speciosa var. lundii A. DC. Of these, the first four occur in the Cerrado biome (GANGA et al., 2010). Currently, Flora do Brasil 2020 (KOCH et al., 2015) recognizes only two varieties: $H$. speciosa Gomes var. speciosa and H. speciosa var. pubescens (Nees \& Mart.) Müll. Arg., although niche modeling studies developed by Collevatti et al. (2018) have partially supported as four varieties occurring in the Cerrado biome. 
The varieties of $H$. speciosa are recognized by the analysis of characteristics such as the presence of leaf trichomes in the variety pubescens and glabrous leaves in the others (RIZZO and FERREIRA, 1990). Other attributes, such as plant height, crown shape, flowering season, number of seeds produced and size, shape, color and mass of the fruits, present high levels of phenotypic variation, making it possible to define some patterns of these characteristics among the varieties (LEDERMAN et al., 2000; GANGA et al., 2009, 2010). The fruits of $H$. speciosa var. gardneri and $H$. speciosa var. pubescens are round, light green in color and larger and heavier than the fruits of the other varieties. The fruits of $H$. speciosa var. speciosa, are dark yellow and those of $H$. speciosa var. cuyabensis are dark green, but both are oblong (GANGA et al., 2010). Although there are macroscopic differences in the fruits, there is no information on whether nutritional quality and the distribution of cells and tissues differs among the varieties.

The fruit of $H$. speciosa possesses great economic potential for agribusiness, however, the extractive exploitation of the fruit limits its consumption to its area of occurrence (LEDERMAN et al., 2000; ARAUJO et al., 2003). The fruit is appreciated by fauna and local people for fresh consumption, as well as in the preparation of various food products, such as juices, popsicles, ice cream, sweets, jellies and liquors (PEREIRA et al., 2010; OLIVEIRA et al., 2017). The fruit is considered a functional food, due to the presence of ascorbic acid, phenolic compounds and carotenoids, in addition having antimutagenic and antioxidant activities (LIMA et al., 2015). Although it has great potential, $H$. speciosa has not yet been domesticated and fruit production is seasonal.

Morphologically, the fruit of $H$. speciosa specie is a fleshy berry-type fruit of varying size, shape and color; it can be ellipsoid or rounded, yellowish or greenish and with or without red pigmentation (PEREIRA et al., 2010). Other species of Apocynaceae (Couma rigida Mull. Arg, Lacmellea panamensis (Woodson) Markgr. and Parahancornia fasciculata (Poir.) Benoist) also possess fleshy berry-type fruits with common anatomical characteristics, such as origination from a syncytial gynecium, unistratified exocarp, cuticle forming cuticular flanges, presence of idioblasts with phenolic and laticiferous compounds, and unistratified endocarp (FREITAS, 2013).

Anatomical constitution is one of the factors that influence the biomechanics of the fruits and, consequently, their quality and conservation (LI et al., 2013). It can also interfere with organoleptic properties due to the presence and location of metabolites. As $H$. speciosa is a single species, our hypothesis is that the general pattern of anatomical organization of fruits can be expected to be similar among its varieties, but since there are morphological differences, some anatomical differences can be expected. Considering the ecological and economic importance of $H$. speciosa, this study aimed to investigate anatomical and histochemical characteristics of the main classes of metabolites of fruits of the four varieties of $H$. speciosa that occur in the Cerrado biome.

\section{MATERIAL AND METHODS}

\section{Plant material}

The fruits of four varieties of $H$. speciosa were collected from trees located in the arboretum (cerrado sensu stricto) of Escola de Agronomia of Universidade Federal de Goiás (UFG), Goiânia-GO, Brazil, in September 2018. The four varieties selected for this study all occur in the Cerrado biome: H. speciosa var. pubescens (16 $35^{\prime} 58^{\prime \prime}$ 'S, 49¹6'46”'W), H. speciosa var. gardneri (16 $\left.35^{\prime} 60^{\prime \prime} \mathrm{S}, 49^{\circ} 16^{\prime} 48^{\prime \prime} \mathrm{W}\right)$, H. speciosa var. 
speciosa (16 $\left.16^{\circ} 6^{\prime} 0^{\prime} \mathrm{S}, 4^{\circ} 16^{\prime} 49^{\prime \prime} \mathrm{W}\right)$ and $H$. speciosa var. cuyabensis $\left(16^{\circ} 35^{\prime} 38^{\prime \prime} \mathrm{S}, 49^{\circ} 17^{\prime} 27^{\prime \prime} \mathrm{W}\right)$.

The fruits were collected at maturation stage unripe, fully expanded and with firm consistency (the very soft consistency of ripe fruits does not allow good anatomical cuts for the methodology used in this work), with lengths $\geq 3 \mathrm{~cm}$ and widths $\geq 2.5 \mathrm{~cm}$. Were collected from three different matrices of each variety. The varieties cuyabensis, gardneri and pubescens have larger fruits (Table 1). The samples were subsequently taken to Laboratório de Anatomia Vegetal of Instituto de Ciências Biológicas of UFG.

Table 1. Average length and width of the fruits of the botanical varieties of Hancornia speciosa Gomes of the arboretum of Escola de Agronomia of Universidade Federal de Goiás (UFG), Goiânia, Brazil (n=3).

\begin{tabular}{lcc}
\hline \multicolumn{1}{c}{ Varieties } & \multicolumn{2}{c}{ Caracteres } \\
& $\mathrm{L}(\mathrm{cm})$ & $\mathrm{W}(\mathrm{cm})$ \\
\hline H. speciosa var.cuyabensis & 4 & 3,5 \\
H. speciosa var.gardneri & 4 & 3,5 \\
H. speciosa var.speciosa & 3,5 & 3 \\
H. speciosa var.pubescens & 4 & 4 \\
\hline
\end{tabular}

L: fruit length; W: fruit width. Source: authors.

\section{Anatomical and histochemical characterization}

Three fruits from three different individuals of each of the studied varieties of $H$. speciosa were selected for anatomical and histochemical study. The fruits were fixed in FPA 50 (formaldehyde, propionic acid, $50 \%$ ethanol) $1: 1: 18(\mathrm{v} / \mathrm{v})$ for $24 \mathrm{~h}(J O H A N S E N$, 1940) and subsequently stored in $70 \%$ ethyl alcohol.

Freehand sections for anatomical analysis were made with the aid of a stainless-steel blade in the median region of the fruits in transversal, longitudinal and paradermic planes. The sections were processed according to standard techniques for anatomical analysis as described in Kraus and Arduin (1997), with astra blue and basic fuchsin.

Histochemical tests were performed on samples of fresh fruits sectioned transversely by free hand. The samples were tested with lugol (JOHANSEN, 1940) for the detection of starch, potassium dichromate (GABE, 1968) and Steinmetz (COSTA, 1970) for phenolic compounds, Sudan IV (JENSEN, 1962) for lipophilic compounds, Miller (MILLER, 1968) for latex and Coomassie blue (FISHER, 1968) for protein. Control sections, without the addition of the histochemical reagents, were performed simultaneously with the tests.

Photomicrographs were obtained using a Leica DM500 microscope with a Leica ICC50 digital camera using the image capture program LAS EZ version 1.8.1. The scales accompanying the illustrations were obtained under the same optical conditions.

\section{RESULTS AND DISCUSSION}

The anatomical description of the pericarp of the fruits of the varieties of $H$. speciosa considered its three regions: exocarp, mesocarp and endocarp (Figure 1A-B). The exocarp constitutes the outer layer of the berry-type fruit, formed by a coating of tissue (Figure 1A). In frontal view, the exocarp of the fruits of the four varieties of $H$. speciosa possesses epidermal cells with thick, straight to slightly-curved anticlinal walls with punctuations (Figure 1C) and anomocytic stomata (Figure 1D) distributed randomly throughout the exocarp. In transverse section, the exocarp is formed by a layer of juxtaposed cells with thick external periclinal walls covered by a thick lipid cuticle and cuticular flanges (Figure 1E). 
Figure 1. Anatomical structure of fruits of varieties of Hancornia speciosa Gomes. A-B, F: Hancornia speciosa var.gardneri (A.DC.) Miers; C-D: Hancornia speciosa Gomes var. speciosa; E: Hancornia speciosa var. cuyabensis Malme. G: Hancornia speciosa var.pubescens (Nees and Mart.) Müll.Arg. A. General aspect of the fruit's pericarp: exocarp and mesocarp. B. General aspect of the endocarp and seed. C. Exocarp cells with straight to slightly curved anticline walls. D. Detail of the stoma in the exocarp (long arrow). E. Uni-stratified exocarp coated with thick cuticle with flange formation (short arrow) - Sudan IV. F-G. Detail of the uni and multicellular trichome. En: endocarp; Ex: exocarp; Me: mesocarp; Se: seed. Bars $=500 \mu \mathrm{m}(\mathrm{A}), 200 \mu \mathrm{m}$ (B), $50 \mu \mathrm{m}$ (C-D, F-G), $25 \mu \mathrm{m}$ (E). Source: authors.
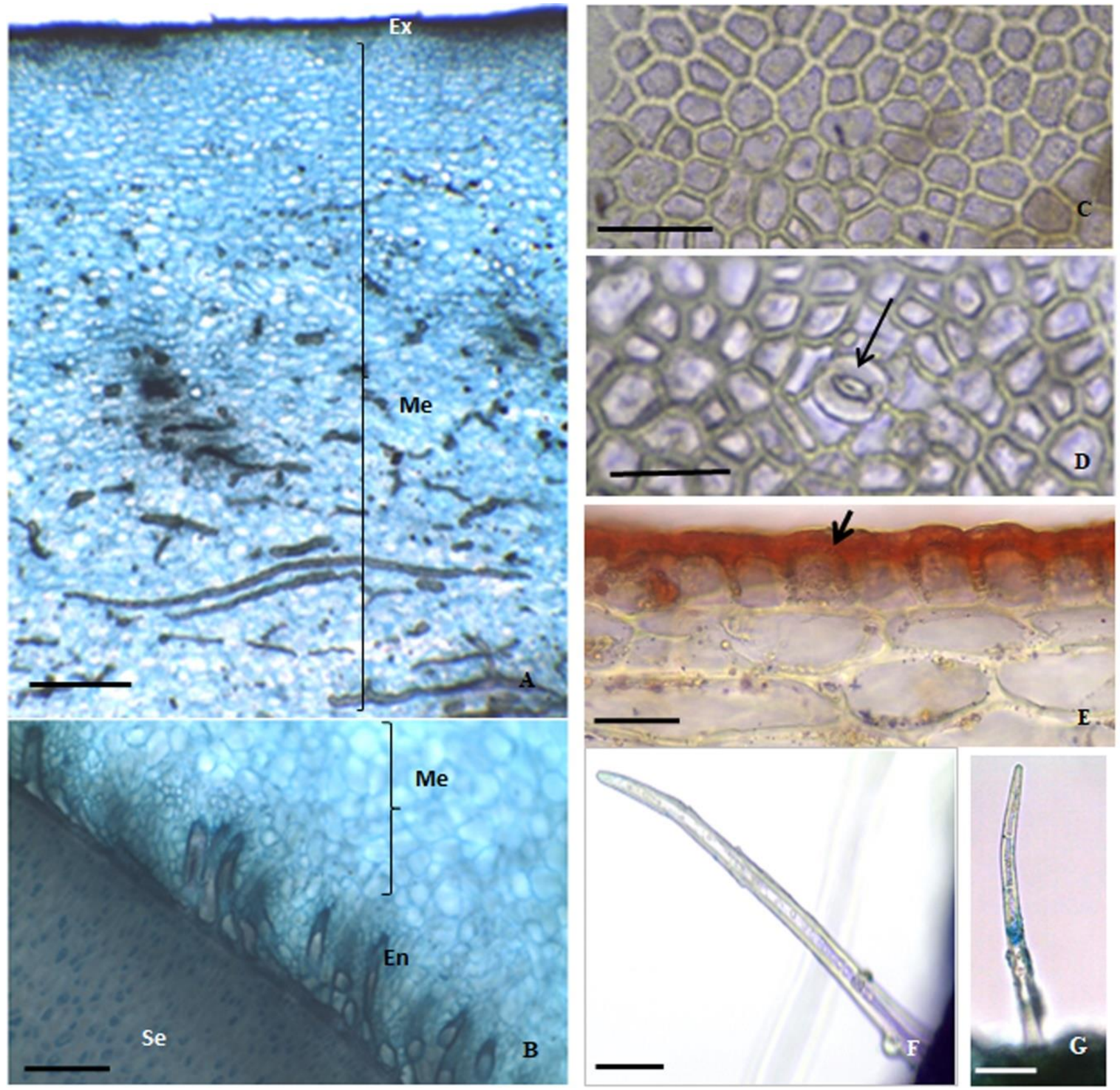

The uniseriate exocarp and covered by a thick cuticle with the presence of flanges and stomata are common anatomical features in fleshy fruits of other species of Apocynaceae (FREITAS, 2013). These characteristics are important for the studied varieties as they tend to protect the plant against excessive transpiration since the cuticle, together with stomata, constitute the interface in the interaction of the fruit with the environment (HANDRO et al., 1970; SCHREIBER et al., 2005). Due to the occurrence of 
plants of this species in more open places, and because they are exposed to high luminosity, the cuticle tends to play a fundamental role in reducing transpiration (FREITAS, 2013). The loss of water through transpiration can interfere with the development of the fruit and the chemical composition of the pulp, thus compromising storage (GIBERT et al., 2010). Thus, the characteristics presented in the exocarp of the fruits of the analyzed varieties of $H$. speciosa are important in maintaining hydration and influencing fruit quality.

Uni- and multicellular trichomes were found in the exocarp of the fruits of all varieties (Figure 1F-G), with the greatest occurrence being in $H$. speciosa var. pubescens and the least in variety cuyabensis. Trichomes are important structures that can help to save water in a plant as they reflect solar radiation that reaches its surface, which helps regulate temperature and prevents increased transpiration (LARCHER, 2000). In addition, trichomes can have taxonomic value in the diagnosis of species, subspecies or varieties, depending on their type and the pattern of occurrence in plant organs (CUTLER et al., 2011).

The mesocarp of all varieties has similar characteristics. It is multi-stratified (Figure 1A), consisting of parenchymatous tissue, idioblasts, laticifers and vascular bundles. The parenchyma has cells with irregular shapes and different sizes; juxtaposed smaller parenchymatous cells with thick walls are present in the layers closest to the exocarp (Figure 2A). There are numerous idioblasts that store phenolic compounds in this region (Figure 2B, Table 2). Internally to these layers, distributed throughout the mesocarp, are isodiametric parenchyma cells with thin walls. Starch grains were observed in these cells only for the variety speciosa.

The mesocarp formed by many layers of cells of parenchymal tissue is a characteristic of fleshy fruits
(PABON-MORA and LITT, 2011). Numerous parenchymal cells with thin walls and fluid content suggest the storage of water and water-soluble substances in their vacuoles, which confers succulence to pulp. No sclerenchyma cells were observed, which interfere with fruit texture, making it more rigid, fibrous or mealy. In addition to the parenchyma, idioblasts containing phenolic compounds occur in the outermost layers of the mesocarp. The presence of these structures has been observed in fruits of other species of Apocynaceae, differing only in their distribution pattern throughout the mesocarp (FREITAS, 2013). Many phenolic compounds act as defense compounds against herbivores and pathogens, while others function as fruit dispersers in protecting against ultraviolet radiation or mechanical support (TAIZ and ZEIGER, 2004). In addition, the degradation of other phenolic compounds, such as tannins, favors the disappearance of the astringent flavor of the fruits (TAIZ et al., 2017). Fruits of mangaba possess a considerable content of phenolic compounds, with emphasis on flavonoids, such as rutin and catechin, and non-flavonoids, such as chlorogenic and gallic acids (LIMA et al., 2015). Studies carried out with aqueous extract of fruits of $H$. speciosa, demonstrated that this species accumulates chlorogenic acid and rutin that can be used as anti-inflammatory substances (TORRES-RÊGO et al., 2016). Due to the location of these substances in association with the exocarp, it is suggested that the fruit be consumed with the peel to obtain their beneficial effects.

Dispersed in the mesocarp, especially in the placental region, are laticifers consisting of a series of interconnected and branched cells that contain latex (Figure 2C). The laticifers observed in the present study were non-articulated and branched, according to the classification of David (1872 in MAHLBERG, 
1993). According to these authors, this type of laticifer occurs in Apocynaceae, Asclepiadaceae, Euphorbiaceae and Moraceae, and is a characteristic of taxonomic value for these botanical families (JUDD et al., 2009) and a common character among the varieties of H. speciosa Gomes.

Figure 2. Location of metabolites and anatomical characteristics of fruits of varieties of Hancornia speciosa Gomes. A, D: Hancornia speciosa var. cuyabensis Malme.; B-C, E: Hancornia speciosa var.pubescens (Nees and Mart.) Müll.Arg. F: Hancornia speciosa Gomes var. speciosa. A. Mesocarp with parenchymal cells - Sudan IV. B. Mesocarp with idioblasts (*). C. Detail of two latex laticifers. D. Collateral vascular bundle detail. E. Trichomes of the seed coat with phenolic compounds. F. Detail of a trichome of the seed coat. CP: parenchymal cell; Ex: exocarp; Fl: phloem; La: laticifers; Me: mesocarp; Se: seed; Tr: trichome; Xi: xylem. Bars: $50 \mu \mathrm{m}$ (A-D, F); $200 \mu \mathrm{m}$ (E). Source: authors.
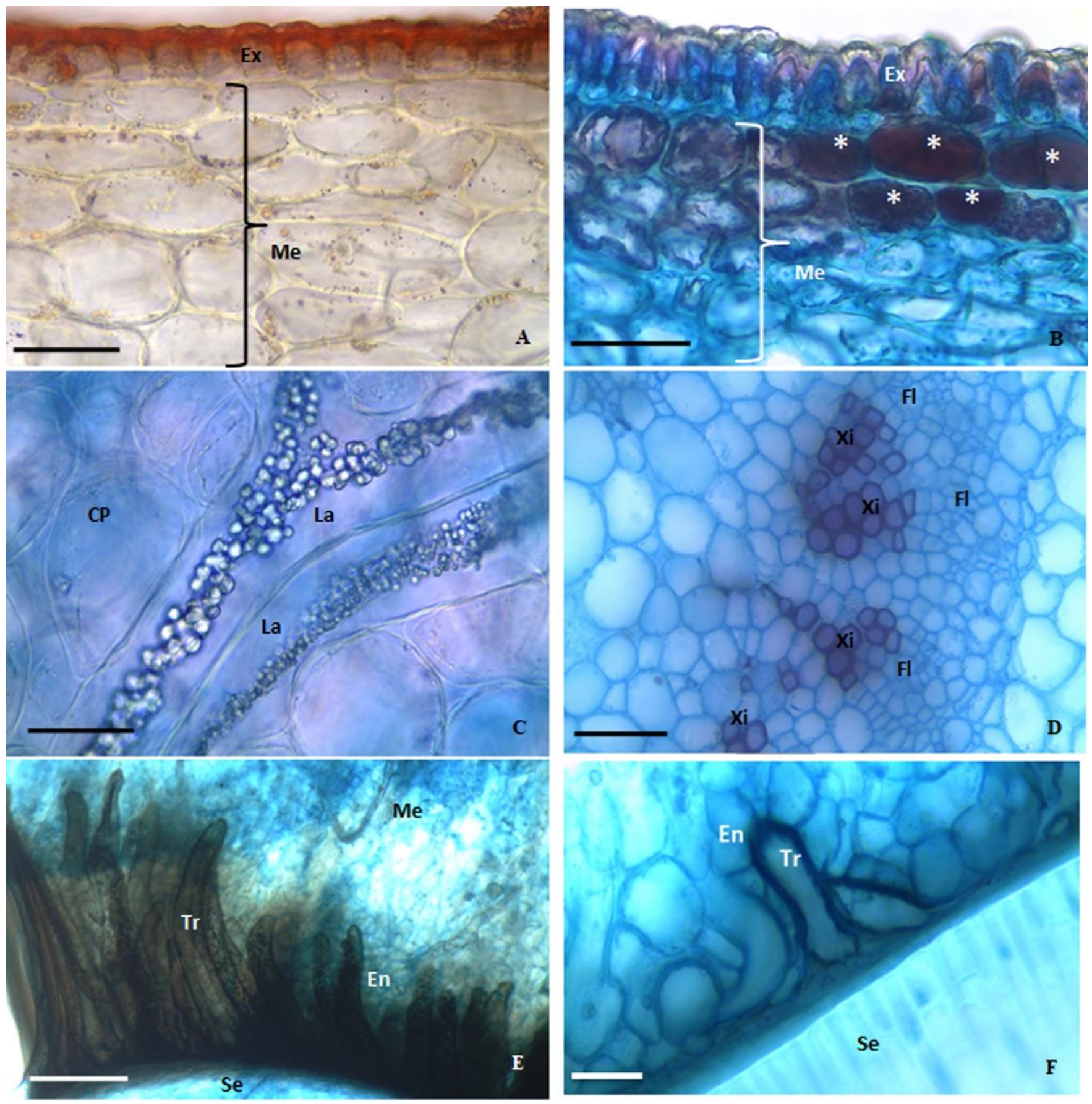
The histochemical tests verified the presence of lipophilic substances in the latex of the analyzed varieties. Fahn (1979) points out that the latex produced in laticifers can have different groups of substances in its composition, including terpenes, starch, waxes, resins, proteins, essential oils, mucilages, carotenoids and fatty acids. Although only lipophilic substances have been detected in latex, this constituent may be relevant due to the wide range of biological activities, as exampled by the ethnobotanical studies, which indicate the latex of $H$. speciosa being used to treat acne, warts, diseases related to bursitis and certain types of inflammation (POTT and POTT, 1994; MARINHO, et al., 2011).

The mesocarp has a vascular system consisting of several collateral vascular bundles without fibers
(Figure 2D). The absence of fibers interferes with the texture of the fruit, giving the soft consistency of the fruit.

The endocarp of all varieties is uni-stratified with a layer of cells with thin walls that surround the seed coat (Figure 1B). The latter consists of trichomes that penetrate between the cells of the endocarp (Figure 2E-F) and that store phenolic compounds in the protoplast (Table 2). Similar results were obtained by Freitas (2013) studying the fruits of $H$. speciosa. These compounds are found in all classes of vascular plants and their importance is related to the defense of tissues against herbivores, fungi, bacteria and viruses, in addition to making the seed coat harder and impermeable (SWAIN, 1979; WERKER, 1997).

Table 2 - Main classes of metabolites detected in the samples of the fruits of the botanical varieties of Hancornia speciosa Gomes from arboretum of Escola de Agronomia of Universidade Federal de Goiás, Goiânia, Brazil (UFG), Goiânia, Brazil.

\begin{tabular}{|c|c|c|c|c|}
\hline Metabolites & $\begin{array}{l}\text { Hancornia speciosa } \\
\text { var. cuyabensis }\end{array}$ & $\begin{array}{l}\text { Hancornia speciosa } \\
\text { var. gardneri }\end{array}$ & $\begin{array}{l}\text { Hancornia speciosa var. } \\
\text { pubescens }\end{array}$ & $\begin{array}{l}\text { Hancornia speciosa var. } \\
\text { speciosa }\end{array}$ \\
\hline Starch & - & - & - & $\begin{array}{l}+ \text { (some parenchymal } \\
\text { cells of the mesocarp) }\end{array}$ \\
\hline $\begin{array}{l}\text { Phenolic } \\
\text { compounds }\end{array}$ & $\begin{array}{l}+ \text { (idioblasts, and } \\
\text { trichomes of the seed } \\
\text { coat) }\end{array}$ & $\begin{array}{l}+ \text { (idioblasts, and } \\
\text { trichomes of the seed } \\
\text { coat) }\end{array}$ & $\begin{array}{l}+ \text { (idioblasts, and } \\
\text { trichomes of the seed coat) }\end{array}$ & $\begin{array}{l}+ \text { (idioblasts, and } \\
\text { trichomes of the seed } \\
\text { coat) }\end{array}$ \\
\hline Latex & + (laticifers) & + (laticifers) & + (laticifers) & + (laticifers) \\
\hline $\begin{array}{l}\text { Lipophilic } \\
\text { compounds }\end{array}$ & $\begin{array}{l}+(\text { cuticle, latex and } \\
\text { seed endosperm })\end{array}$ & $\begin{array}{l}+(\text { cuticle, latex and } \\
\text { seed endosperm })\end{array}$ & $\begin{array}{l}+(\text { cuticle, latex and seed } \\
\text { endosperm })\end{array}$ & $\begin{array}{l}+(\text { cuticle, latex and } \\
\text { seed endosperm })\end{array}$ \\
\hline Proteins & $\begin{array}{l}+ \text { (cell walls, mainly } \\
\text { of the conduction } \\
\text { tissue, the endosperm } \\
\text { and the seed coat). }\end{array}$ & $\begin{array}{l}+ \text { (cell walls, mainly } \\
\text { of the conduction } \\
\text { tissue, the endosperm } \\
\text { and the seed coat). }\end{array}$ & $\begin{array}{l}+(\text { cell walls, mainly of the } \\
\text { conduction tissue, the } \\
\text { endosperm and the seed } \\
\text { coat). }\end{array}$ & $\begin{array}{l}+ \text { (cell walls, mainly of } \\
\text { the conduction tissue, } \\
\text { the endosperm and the } \\
\text { seed coat). }\end{array}$ \\
\hline
\end{tabular}

(-) absence; (+) presence of metabolites. Source: authors.

In addition to the reported metabolites, proteins were detected in association with cell walls, with no structures that stored these compounds being observed 
and in the seed coat. Fruit pulp, in general, is not considered a good source of protein, and their composition in $H$. speciosa is less than 1\% (ALMEIDA et al., 2008). Starch was observed only in H. speciosa var. speciosa. Starch is a reserve carbohydrate that is hydrolyzed in fruit during the ripening process for the release of sugars giving the sweet taste (TAIZ et al., 2017). The presence of starch in this variety evidences the course of the ripening process, that will be followed by the increase in its total soluble solid content, as according to Carnelossi et al. (2009).

The present study analyzed fruits in the maturation process, and the anatomical characteristics observed are similar to those presented by Freitas (2013) in anatomical studies with ripe fruits of $H$. speciosa, demonstrating that the structural part of the unripe fruit is already formed. Regarding the histochemical characteristics, as the fruit ripening process involves several metabolic reactions (TAIZ et al., 2017), the types of compounds as their contents can be changed as the fruit becomes ripe.

\section{CONCLUSION}

The fruits of the four studied varieties of $H$. speciosa presented similar cellular and tissue arrangement, and with characteristics common to fleshy fruits of other species of Apocynaceae.

The H. speciosa fruits showed uni-stratified exocarp with the presence of stomata; mesocarp well developed with parenchymal cells, idioblasts with accumulations of phenolic compounds, numerous laticifers and few vascular bundles; and uni-stratified endocarp surrounding the seed coat. The fruits of the varieties differed in the occurrence of trichomes in the exocarp.

The presence of phenolic compounds, latex, lipids, and proteins, with similar locations in the fruits of the different varieties of $H$. speciosa, indicates that the quality of these fruits may be similar.

Further anatomical studies of other organs of the different varieties of $H$. speciosa are necessary, as they may contribute to the differences, and/or similarities existing in each of the varieties described by Monachino (1945).

\section{ACKNOWLEDGEMENTS}

The Fundação de Apoio à Pesquisa do Estado de Goiás - FAPEG for a $\mathrm{PhD}$ fellowship (proc. 201810267000629/2018-03) and Coordenação de Aperfeiçoamento de Pessoal de Nível Superior CAPES for a $\mathrm{PhD}$ fellowship (proc. $\mathrm{n}^{\circ}$ 88882.385950/2019-01).

All authors have declared that there is no potential conflict of interest regarding this article.

\section{REFERENCES}

ALMEIDA, S. P.; COSTA, T. S. A.; SILVA, J. A. Frutas nativas do Cerrado: caracterização físicoquímica e fonte potencial de nutrientes. In: SANO, S. M.; ALMEIDA, S. P. de; RIBEIRO, J. F. (Eds), Cerrado - Ecologia e Flora. Embrapa Cerrados. Brasília- DF, p. 351-381; 2008.

ARAUJO, I. A.; FRANCO, C. F. O; BARREIRO NETO, M.; FONTINÉLLI, I. S. C. Avaliação Fenológica dos Frutos de Progênies de Mangabeira Cultivadas no Litoral Paraibano. In: Anais. I Simpósio Brasileiro sobre a Cultura da Mangaba. Aracaju, SE: Embrapa semiárido, dez. 2003.

CARNELOSSI, M. A. G.; SENA, H. C. de; NARAIN, N.; YAGUIU, P.; SILVA, G. F. da. Physico-chemical quality changes in mangaba (Hancornia speciosa Gomes) fruit stored at different temperatures. Braz. Arch. Biol. Technol. v. 52, n. 4, p. 985-990, 2009.

COLLEVATTI, R. G.; RODRIGUES, E. E.; VITORINO, L. C; LIMA-RIBEIRO, M. S.; CHAVES, L. J.; TELLES, M. P. C. Unravelling the genetic differentiation among varieties of the Neotropical savanna tree Hancornia speciosa Gomes. Ann. Bot. v. 122, n. 6, p. 973-984, 2018. 
COSTA, A. F. Farmacognosia, (Farmacognosia Experimental) 2ed. Lisboa, Fundação Calouste Gulbenkian, 1970.

CUTLER, D. F.; BOTHA, T. STEVENSON, D.W. Anatomia Vegetal: uma abordagem aplicada. Porto Alegre: Artmed, 2011.

FAHN, A. Secretory tissues in plants. Academic Press Inc., London, 1979.

FISHER, D.B. Protein staining of ribboned epon sections for light microscopy. Histochemie v. 16, p. 92-96, 1968.

FREITAS, C. C. M. Morfologia e Anatomia de frutos e sementes da tribo Willughbeieae (Apocynaceae, Rauvolfioideae). Dissertação de Mestrado. Universidade Estadual de Campinas, Campinas, SP; 2013.

GABE, M. Techniques histologiques. Masson \& Cie, Paris, 1968.

GANGA, R. M. D.; CHAVES, L.J.; NAVES, R. V. Parâmetros genéticos em progênies de Hancornia speciosa Gomes do Cerrado. Sci. For. v. 37, n. 84, p. 395-404, 2009.

GANGA, R.M.D.; FERREIRA, G.A.; CHAVES, L.J; NAVES, R.V.; NASCIMENTO, J.L. Caracterização de frutos e árvores de populações naturais de Hancornia speciosa Gomes do cerrado. Rev. Bras. Frutic. v. 32, n. 1, p. 101-113, 2010.

GIBERT, C.; GENARD, M. VERCAMBRE, G.; F. LESCOURRET. Quantification and modelling of the stomatal, cuticular and crack components of peach fruit surface conductance. Funct. Plant Biol. v. 37, p. 264-274, 2010.

JENSEN, W. A. Botanical histochemistry, principles and practice. W. H. Freeman, San Francisco, 1962.

JOHANSEN, D.A. Plant microtechnique. McGraw-Hill Book Company Inc, New York, 523p., 1940.

JUDD, W. S.; CAMPBELL, C. S.; KELLOGG, E. A.; STEVENS, P. F.; DONOGHUE, M. J. Sistemática vegetal: um enfoque filogenético. In: SIMÕES, A. O.; SINGER, R. B.; SINGER, R. F.; CHIES, T. T. S. (Trad.). Porto Alegre: Artemd, 3ed., 2009.
HANDRO, W.; CAMPOS, J. F. B. de M.; OLIVEIRA, Z. M. Sobre a anatomia foliar de algumas compostas dos campos rupestres. Cien. Cult. v. 22, p. 107-126, 1970.

KOCH, I.; RAPINI, A.; SIMÕES, A.O.; KINOSHITA, L. S.; SPINA, A. P.; CASTELLO, A. C. D. 2015. Apocynaceae in Lista de Espécies da Flora do Brasil. Jardim Botânico do Rio de Janeiro. Disponivel em: $<$ http://floradobrasil.jbrj.gov.br/jab ot/floradobrasil/FB15558 $>$.

KRAUS, J. E.; ARDUIN, M. Manual Básico de Métodos em Morfologia Vegetal. Seropédica, RJ: EDUR, 1997.

LARCHER, W. EcofisiologiaVegetal. São Carlos, SP Editor: Rima, 531p., 2000.

LEDERMAN, I. E.; SILVA JÚNIOR, J. F.; BEZERRA, J. E. F.; ESPÍNDOLA, A. C. M. Mangaba (Hancornia speciosa Gomes). Jaboticabal: FUNEP, 2000.

LI, Z., YANG, H., LI, P., LIU, J., WANG, J., XU, Y. Fruit biomechanics based on anatomy: a review. Int. Agrophys. vol. 27, n. 1, p. 97-106, 2013.

LIMA, J.P.; AZEVEDO, L.; SOUZA, N.J.; NUNES, E.E.;VILAS BOAS, E.V.B. First evaluation of the antimutagenic effect of mangaba fruit in vivo and its phenolic profile identification. Food Res. Int. v. 75, p. 216-224, 2015.

MAHLBERG, P. G. Laticifers: An Historical Perspective. Bot. Rev. vol. 59, p. 1-23, 1993.

MARINHO, D.G.; ALVIANO, D.S.; MATHEUS, M.E.; ALVIANO, C.S.; FERNANDES, P.D. The látex obtained from Hancornia speciosa Gomes possesses anti-inflammatory activity. J. Ethnopharmacol. v. 135, p. 530-537, 2011.

MILLER, L. Apostila do curso de microtécnica e fotomicrografia. São Paulo. Escola Superior de Agricultura "Luiz de Queiroz", 1968.

MONACHINO, J. A revision of Hancornia (Apocynaceae). Lilloa v. 11, p. 19-48, 1945.

OLIVEIRA, D. M.; CRUZ, D. S.; FREITAS, B. A. L.; GOMES, L. J. Coletânea bibliográfica acadêmica sobre a mangabeira (Hancornia speciosa Gomes). Gaia Scientia v. 11, n. 3, p. 212-231, 2017. 
PABON-MORA, N.; LITT, A. Comparative anatomical and developmental analysis of dry and fleshy fruits of Solanaceae. Am. J. Bot. v. 98, n. 9, p. 1415-1436, 2011.

PEREIRA, A. V.; PEREIRA, E. B. C.; JÚNIOR, J. F. S.; SILVA, D. B. Mangaba. In: VIEIRA, R. F.; AGOSTINI-COSTA, T. S.; SILVA, D. B.; SANO, S. M.; FERREIRA, F. R (eds.), Frutas nativas da região Centro-Oeste do Brasil. Brasília, DF: Embrapa Informação Tecnológica, p. 221-246, 2010.

POTT, A.; POTT, V. J. Plantas do Pantanal. Brasília, Embrapa, 1994.

RIZZO, J.A.; FERREIRA, H.D. Hancornia G., no estado de Goiás. In: CONGRESSO NACIONAL DE BOTÂNICA 36, 1985, Curitiba, PR. Anais. v.2, p.691-707,1990.

SCHREIBER, L. Polar paths of diffusion across plant cuticles: new evidence for an old hypothesis. Ann. Bot. v. 95, p. 1069-1073, 2005.

SWAIN, T. Tanins and lignins. In: G. A. ROSENTHAL; D.H. JANSEN (eds.), Herbivores: their interactions with secondary plant metabolites. Academic Press, New York, p. 657682:1979.

TAIZ, L.; ZEIGER, E. Fisiologia Vegetal. 3. ed. Porto Alegre: Artmed, 2004.

TAIZ, L. ZEIGER, E.; MOLLER, I.M.; MURPHY, A. Fisiologia e Desenvolvimento Vegetal. 6. ed. Porto Alegre: Artmed, 2017.

TORRES-RÊGO, M.; FURTADO, A. A.; BITENCOURT, M. A. O.; LIMA, M. C. J.de S.; ANDRADE, R. C. L. C. de; AZEVEDO, E. P. de; SOARES, T. C.; TOMAZ, J. C.; LOPES, N. P.; SILVA-JUNIOR, A. A.; ZUCOLOTTO, S. M; Fernandes-Pedrosa, M. de F. Anti-inflammatory activity of aqueous extract and bioactive compounds identified from the fruits of Hancornia speciosa Gomes (Apocynaceae). BMC Complement. Alt. Med. v. 16, n. 275, p. 1-10, 2016.

WERKER. E. Seed Anatomy. 2ed. Speziellertell. Publisher: Borntraeger ,1997. 